\title{
A nondystopian alternative history?
}

\author{
James S. Tweddell, MD
}

\author{
From the Heart Institute, Cincinnati Children's Hospital Medical Center, Cincinnati, Ohio. \\ Disclosures: Author has nothing to disclose with regard to commercial support. \\ Received for publication July 28, 2017; accepted for publication July 31, 2017; available ahead of print Sept 6 , \\ 2017. \\ Address for reprints: James S. Tweddell, MD, Cincinnati Children's Hospital Medical Center, Heart Institute, \\ 3333 Burnet Ave, MLC 2013, Cincinnati, OH 45229-3026 (E-mail: James.Tweddell@ cchmc.org). \\ J Thorac Cardiovasc Surg 2018;156:773-4 \\ $0022-5223 / \$ 36.00$ \\ Copyright (C 2017 by The American Association for Thoracic Surgery \\ http://dx.doi.org/10.1016/j.jtcvs.2017.07.054
}

In this September 2017 issue of the Journal, Broberg and colleagues $^{1}$ provide an excellent, remarkably detailed summary of the emergence of the arterial switch operation for dextrotransposition of the great arteries (D-TGA). It is a remarkable story indeed of how the success of a handful of cases in Brazil led to a revolution in the management of D-TGA and with it ushered in the era of neonatal cardiac surgery. Broberg and colleagues ${ }^{1}$ also bring up the challenging issue of surgical innovation and cost in human lives of developing a new therapy with the potential for improved long-term survival, but at the cost of a higher early mortality, particularly as surgeons and programs begin to gain experience with a new procedure. They question whether the arterial switch operation could have been developed in our current environment of increased transparency, a team approach to patient care, and group decision making. The concept of a learning curve (Figure 1) is well understood in the field of medicine, but is certainly less appreciated by the nonmedical public. And although it is commonly accepted in medicine, few of us would tolerate a learning curve in other areas in which human, particularly our own, lives are at stake, such as air transport, chemical plants, or nuclear power generation.

Has transparency stifled innovation? There is, I believe a sense among the surgical community, one echoed in this review by Broberg and colleagues, that transparency, particularly public reporting, has diminished innovation and that patients are more frequently "relegated" to the procedure with the lowest short-term mortality. This is often cited as an unintended consequence of public reporting. Indeed, the current Society of Thoracic Surgeons risk adjustment system uses operative mortality as the end point. $^{2,3}$ In an attempt to display the best possible outcomes for their programs, it is suggested that surgeons may opt for what they believe to be a lower risk palliative option, even though the cumulative outcome for a specific patient may be better with an earlier complete repair. Whether there are such low-risk options for immediate palliation and whether this is actually happening to any degree is unknown. Although I understand the longing for

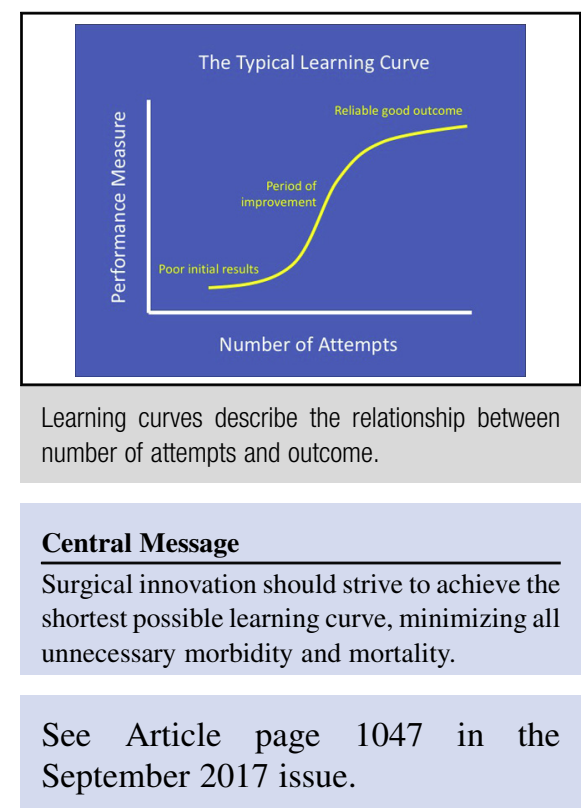

the good old days, when innovation was primarily between the surgeon and patient, the authority gradient cannot be ignored. The corollary of the notion that transparency stifles innovation, and one that I believe all my colleagues would soundly reject, is the idea that innovation can only thrive when outcomes are concealed or at least made opaque.

The arterial switch operation is one of the great success stories of congenital heart surgery, and so it is all the more discouraging to think that this success was only made possible by the unnecessary loss of human lives as surgeons and programs toiled in isolation through their individual learning curves. Could it have been different? Some recent examples of surgical innovation suggest that it could. During the last 2 decades, innovative surgical approaches have developed, shown initial promise, and been subjected to randomized, controlled trials that identified the risk-benefit ratio, narrowed selection criteria, and identified important contraindications. Among these are lung-volume reduction surgery for severe emphysema, which showed improved exercise capacity but little survival benefit, despite a sound theoretic basis. ${ }^{4}$ The Single Ventricle Reconstruction Trial showed that the right ventricle-to-pulmonary artery conduit modification of the Norwood procedure had improved 1-year survival relative to the Norwood procedure with a systemic-to-pulmonary artery shunt but that this survival advantage was lost by 3 years. $^{5,6}$ But perhaps it is the introduction of transcatheter aortic valve replacement (TAVR) and the PARTNER (Placement of AoRTic TraNscathetER) trials 


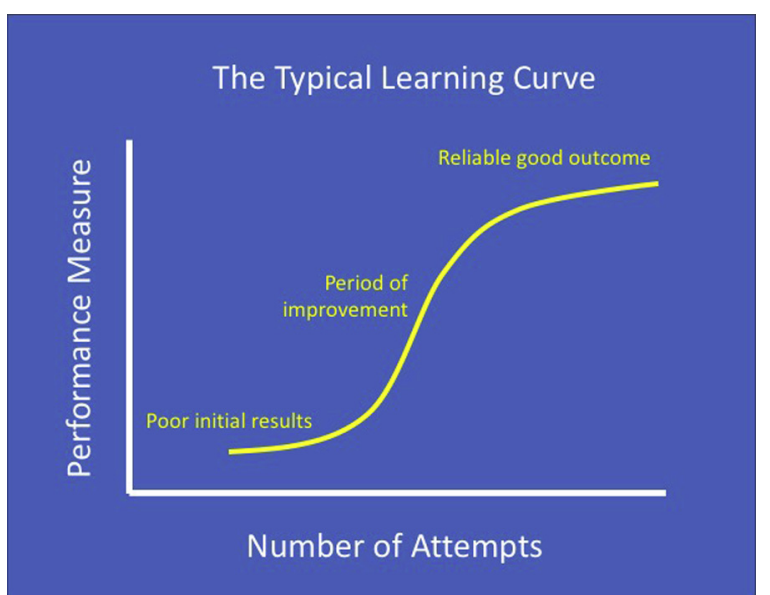

FIGURE 1. Learning curves describe the relationship between the number of attempts and the outcome of a procedure. Although well accepted in medical training, the concept is probably little known to the nonmedical public. Surgical innovation should strive to achieve the shortest possible learning curve, minimizing all unnecessary morbidity and mortality.

that provide a framework that could have been used for the introduction of the atrial switch operation. The PARTNER trials began by identifying a group of patients who were considered too high risk for standard surgical aortic valve replacement. ${ }^{7}$ A survival benefit to TAVR was identified among these non-surgical patients; in addition, important lessons were learned, techniques were refined, and the studies on TAVR have been extended to high-risk and now even intermediate-risk patients. ${ }^{8,9}$ Among patients with D-TGA, those with a ventricular septal defect were well known to have an increased mortality risk. There were reports in the 1980s of mortality for the atrial level switch combined with a ventricular septal defect that were the same as for the early experience with the arterial switch operation, between $15 \%$ and $20 \% .^{10,11}$ Could organized efforts with the arterial switch operation have been directed at those individuals with D-TGA and ventricular septal defect, for whom there was equipoise with the atrial level switch? In particular, could the operation have been initially concentrated at a few wellprepared centers? Coronary transfer techniques could have been refined, and the success with this group could have led to the extension to the higher risk neonatal group. Although we might have gotten there more slowly, perhaps we would have a few more adult survivors of D-TGA today-alive with an atrial switch, but alive nonetheless.

Broberg and colleagues ${ }^{1}$ suggest that the excess mortality of the introduction of the arterial switch could not be avoided and was therefore justified. Alternate history is a popular genre of fiction in which historical events occur differently, generally with dystopian "what if" scenarios. Examples include Phillip Dick's Man in the High Castle and Ben Winters' excellent novel, Underground Airlines, both of which describe a very bleak current era if history had turned out a bit differently. ${ }^{12,13}$ Perhaps a nondystopian alternative history in which the arterial switch operation was introduced through a transparent, collaborative, methodic, stepwise approach similar to the introduction of TAVR and that would have followed the guidelines developed by the Society of University Surgeons would have allowed the introduction of this lifesaving procedure at the lowest possible human cost. ${ }^{14}$

\section{References}

1. Broberg CS, Shen I, Menashe V, Starr A. Emergence of the arterial switch procedure for transposition of the great arteries and the potential cost of surgical innovation. J Thorac Cardiovasc Surg. 2017;154:1047-51.

2. Jacobs JP, O'Brien SM, Pasquali SK, Gaynor JW, Mayer JE Jr, Karamlou T, et al. The Society of Thoracic Surgeons Congenital Heart Surgery Database mortality risk model: part 2-clinical application. Ann Thorac Surg. 2015;100:1063-8; discussion 1068-70.

3. O'Brien SM, Jacobs JP, Pasquali SK, Gaynor JW, Karamlou T, Welke KF, et al. The Society of Thoracic Surgeons Congenital Heart Surgery Database mortality risk model: part 1-statistical methodology. Ann Thorac Surg. 2015;100: 1054-62.

4. Fishman A, Martinez F, Naunheim K, Piantadosi S, Wise R, Ries A, et al. National Emphysema Treatment Trial Research Group. A randomized trial comparing lung-volume-reduction surgery with medical therapy for severe emphysema. N Engl J Med. 2003;348:2059-73.

5. Ohye RG, Sleeper LA, Mahony L, Newburger JW, Pearson GD, Lu M, et al. Pediatric Heart Network Investigators. Comparison of shunt types in the Norwood procedure for single-ventricle lesions. N Engl J Med. 2010;362:1980-92.

6. Newburger JW, Sleeper LA, Frommelt PC, Pearson GD, Mahle WT, Chen S, et al. Transplantation-free survival and interventions at 3 years in the Single Ventricle Reconstruction Trial. Circulation. 2014;129:2013-20.

7. Leon MB, Smith CR, Mack M, Miller DC, Moses JW, Svensson LG, et al; PARTNER Trial Investigators. Transcatheter aortic-valve implantation for aortic stenosis in patients who cannot undergo surgery. N Engl J Med. 2010;363:1597-607.

8. Smith CR, Leon MB, Mack MJ, Miller DC, Moses JW, Svensson LG, et al; PARTNER Trial Investigators. Transcatheter versus surgical aortic-valve replacement in high-risk patients. N Engl J Med. 2011;364:2187-98.

9. Leon MB, Smith CR, Mack MJ, Makkar RR, Svensson LG, Kodali SK, et al; PARTNER 2 Investigators. Transcatheter or surgical aortic-valve replacement in intermediate-risk patients. N Engl J Med. 2016;374:1609-20.

10. Penkoske PA, Westerman GR, Marx GR, Rabinovitch M, Freed MD, Norwood WI, et al. Transposition of the great arteries and ventricular septal defect: results with the Senning operation and closure of the ventricular septal defect in infants. Ann Thorac Surg. 1983;36:281-8.

11. Norwood WI, Dobell AR, Freed MD, Kirklin JW, Blackstone EH. Intermediate results of the arterial switch repair. A 20-institution study. J Thorac Cardiovasc Surg. 1988;96:854-63.

12. Dick P. Man in the high castle. New York: Vintage Books; 1962.

13. Winters B. Underground airlines. New York: Random House; 2016.

14. Biffl WL, Spain DA, Reitsma AM, Minter RM, Upperman J, Wilson M, et al; Society of University Surgeons Surgical Innovations Project Team. Responsible development and application of surgical innovations: a position statement of the Society of University Surgeons. J Am Coll Surg. 2008;206: 1204-9. 